\title{
PENGARUH TEKNIK MIND MAPPING TERHADAP KETERAMPILAN BERBICARA PESERTA DIDIK KELAS IX SMP NEGERI 1 PARIAMAN
}

\author{
Wina Widia ${ }^{1)}$; Erika Wulandari ${ }^{2)}$ Afnita $^{3 \text { ) }}$ \\ ${ }^{1}$ Universitas Negeri Padang, Padang; winawidia300@ gmail.com \\ ${ }^{2}$ Universitas Negeri Padang, Padang; erikawulandari486@gmail.com \\ ${ }^{3}$ Universitas Negeri Padang, Padang; afnita@fbs.unp.ac.id
}

\begin{abstract}
The purpose of this study was to determine the effect of using mind mapping techniques on speaking skills of class IX students of SMP Negeri 1 Pariaman. The instrument used in this study is the performance test. The data of this study is the score of the test results of students' speaking skills at the pretest and posttest. Data were analyzed by percentage formula, formula for calculating averages and t-test. The results of the study concluded the following three things. First, the speaking skills of class IX students at the pretest were more than qualified with an average value of $66.78 \%$. Second, students speaking skills at the time of posttest were in Good qualification with an average value of $81.78 \%$. Third, the alternative hypothesis (1) was received at a significant level of $95 \%$ and $d k=n-1$ because tcount $>t$ table (7.23-1.71). In other words, the use of mind mapping techniques significantly influences the speaking skills of class IX students of SMP Negeri 1 Pariaman.
\end{abstract}

Keywords: Mind Mapping Technique, Speaking

\begin{abstract}
ABSTRAK
Tujuan penelitian ini adalah untuk mengetahui pengaruh penggunaan teknik mind mapping terhadap keterampilan berbicara peserta didik kelas IX SMP Negeri 1 Pariaman. Instrumen yang digunakan dalam penelitian ini yaitu tes unjuk kerja. Data penelitian ini adalah skor hasil tes keterampilan berbicara peserta didik saat pretest dan posttest. Data dianalisis dengan rumus presentase, rumus ratarata hitung dan uji-t.Hasil penelitian disimpulkan tiga hal berikut. Pertama, keterampilan berbicara peserta didik kelas IX pada saat pretest berada pada kualifikasi lebih dari cukup dengan nilai rata-rata $66,78 \%$. Kedua, keterampilan berbicara peserta didik pada saat posttest berada berada pada kualifikasi Baik dengan nilai rata-rata $81,78 \%$. Ketiga, hipotesis alternatif $(\mathrm{H})$ diterima pada taraf signifikan $95 \%$ dan $\mathrm{dk}=\mathrm{n}-1$ karena thitung $>\operatorname{ttabel}(7,23>1,71)$. Dengan kata lain, penggunaan teknik mind mapping berpengaruh secara signifikan terhadap keterampilan berbicara peserta didik kelas IX SMP Negeri 1 Pariaman.
\end{abstract}

Kata Kunci: Teknik Mind Mapping, Berbicara

\section{PENDAHULUAN}

Kegiatan pembelajaran berbahasa merupakan kegiatan berkomunikasi menggunakan bahasa. Pembelajaran bahasa Indonesia diarahkan untuk meningkatkan kemampuan peserta didik berkomunikasi baik secara lisan maupun tulisan. Keterampilan berbahasa sesuai dengan hakikat pembelajaran bahasa yakni terampil mendengarkan, berbicara, membaca, dan menulis.Salah satu cara untuk meningkatkan keterampilan berbahasa peserta didik adalah melalui keterampilan berbicara. 
Keterampilan berbicara merupakan bentuk komunikasi yang penting dalam kehidupan sehari-hari. Setiap manusia yang normal di dunia akan melakukan kegiatan berbicara dalam menjalani hidupnya. Mulai dari masa kanak-kanak hingga tua kegiatan berbicara tidak pernah ditinggalkan. Bahkan seluruh aspek kehidupan ditandai dengan kegiatan berbicara. Suryaman (2009) mengungkapkan bahwa salah satu tujuan dari mata pelajaran bahasa Indonesia ialah mampu berkomunikasi secara efektif dan efisien sesuai dengan etika yang berlaku, baik lisan maupun tulis.

Berbicara memiliki pengertian yang luas. Dalam penelitian ni, berbicara lebih difokuskan kepaa keterampilan peserta didik berbicara di baik di dalam kelas maupun di tempat umum. Berbicara merupakan keterampilan berbahasa yang bersifat produktif lisan. Menurut Tarigan (2008:16) berbicara adalah kemampuan mengucapkan bunyi-bunyi artikulasi atau kata-kata untuk mengekspresikan, menyatakan, atau menyampaikan pikiran gagasan, dan perasaan. Suhendar (2012) mengungkapkan bahwa berbicara adalah kegiatan menyampaikan pikiran atau perasaan kepada orang lain melalui ujaran, yaitu menyampaikan pikiran atau perasaan kepada orang lain secara lisan. Selanjutnya Arif dan Munaf (2003:11) menyatakan bahwa berbicara bukanlah sekedar pengucapan bunyi-bunyi atau kata-kata, tetapi berbicara merupakan suatu alat untuk menyampaikan gagasan yang disusun dan dikembangkan sesuai dengan kebutuhan pendengar atau penyimak. Berdasarkan pendapat di atas, dapat disimpulkan bahwa berbicara merupakan suatu kegiatan interaksi antara pembicara dan pendengar dalam bentul lisan untuk meyampaikan tujuan atau maksud tertentu.

Pembelajaran keterampilan berbicara membutuhkan metode tertentu yang dapat memberikan kesempatan untuk peserta didik mencapai tujuan yang dicita-citakan. Karena dengan menggunakan metode yang sesuai dengan pembelajaran maka peserta didik dengan mudah dapat menguasai pelajaran dengan baik. Untuk itu, perlu adanya penelitian yang mengungkapkan permasalahan dan mencari solusi menyelesaikan permasalahan tersebut. Salah satu cara yang dipandang cocok untuk pemecahan masalah rendahnya keterampilan berbicara peserta didik adalah melalui penggunaan teknik mind mapping. Penerapan Teknik mind mapping diharapkan dapat berbicara dengan mudah karena mind mapping merupakan suatu cara pembelajaran yang dapat membantu mengingat dengan menggunakan peta pikiran.

Mind mapping adalah sebuah strategi dalam pembelajaran yang berusaha mengaktifkan otak kanan dan otak kiri. Mind mapping merupakan suatu cara pembelajaran yang dapat membantu mengingat dengan menggunakan peta pikiran. Mind mapping memiliki struktur alami yang memancar dari pusat, menggunakan garis lengkung, simbol, kata, dan gambar yang sesuai dengan satu rangkaian aturan yang sederhana mendasar, alami, dan sesuai dengan cara kerja otak. Teknik ini dalam pembelajaran keterampilan berbicara dapat membantu peserta didik dalam 
mengingat pembicaraan yang akan dilakukan dengan cara meringkas keseluruhan isi pembicaraan menjadi satu halaman. Membuat catatan dengan cara ini dapat membantu peserta didik memusatkan konsentrasi dan mengalihkan pikiran kembali pada apa yang sedang dibicarakan. Melalui teknik mind mapping diharapkan peserta didik mampu memfokuskan serta menata dengan baik pengetahuan dan pengalaman yang dimilikinya mengenai tokoh idola ke dalam bahasa lisan.

Berdasarkan wawancara dengan Ibu Gusti Roza, salah satu guru bahasa Indonesia di SMP Negeri 1 Pariaman yang mengajar kelas IX, terdapat empat indikasi permasalahan dalam keterampilan berbicara peserta didik. Permasalahan tersebut sebagai berikut. Pertama, peserta didik berbicara dengan volume yang kecil, sehingga yang disampaikan peserta didik tidak jelas dan inti pembicaraan peserta didik tidak dapat diterima pendengar secara utuh. Kedua, peserta didik cenderung tidak memiliki keberanian untuk berbicara ketika diberi tugas tampil di depan kelas, menanggapi, mengajukan, dan menjawab pertanyaan dari guru secara lisan. Ketiga, peserta didik tidak mampu berimprovisasi ketika menyampaikan sesuatu karena terdokus pada teks, sehingga pendengar tidak dapat memahami makna yang disampaikan. Keempat, peserta didik tidak mampu berbicara sesuasi dengan intonasi yang semestinya sehingga apa yang disampaikan tidak mendapat perhatian atau tidak menarik dan bahkan maksud yang diterima pendengar akan berbeda.
Pembelajaran keterampilan berbicara juga membutuhkan teknik tertentu agar dapat memberikan kesempatan untuk peserta didik mencapai tujuan yang dicita-citakan. Oleh sebab itu, perlu adanya penelitian yang mengungkapkan permasalahan serta mencari solusi terhadap masalah ini. Salah satu cara yang cocok untuk pemecahan masalah rendahnya keterampilan berbicara peserta didik ialah melalui penggunaan teknik mind mapping.

Teknik mind mapping merupakan teknik pembelajaran dengan menggunakan peta pikiran. Teknik ini merupakan salah satu teknik yang dapat merangsang peserta didik untuk berpikis kreatif dalam menuangkan ide, gagasan, pendapat, dan pikirannya ke dalam sebuah tulisan. Teknik dapat menghilangkan kebosanan peserta didik dalam mencata sehingga otak peserta didik akan lebih cepat mengingat, mencerna, dan mengembangkan catatan yang telah dibuat. Aini dkk (2012:127) mengungkapkan bahwa penggunaan mind mapping dalam pembelajaran dapat mengaitkan otak kanan dan otak kiri secara seimbang. Sejalan dengan pendapat di atas, Immaduddin, dkk (2012) menyatakan bahwa mind mapping merupakan suatu teknis grafis yang dapat menyelaraskan proses belajar dengan cara kerja alami otak. Mind mapping menggunakan otak kanan sehingga proses pembuatannya menyenangkan dan merupakan cara yang paling efektif dan efisien untuk memasukkan, menyimpan, dan mengeluarkan data yang ada di dalam memori otak kita.

Berdasarkan penjabaran di atas, fokus penelitian ini adalah hal-hal berikut. Pertama, 
penelitian difokuskan pada penerapan teknik mind mapping. Secara teoritis dan empiris, teknik mind mapping efektif diterapkan dalam pembelajaran keterampilan berbicara. Selain itu, penerapan teknik ini juga dapat dilaksanakan secara berkelompok sehingga peserta didik bisa bekerja sama dengan yang lainnya dan bisa saling bertukar pikiran. Kedua, penelitian ini difokuskan pada keterampilan berbicara dalam kegiatan bercerita dengan indikatar (1) lafal dan intonasi, (2) struktur bahasa, (3) pilihan kata, (4) kalancara, (5) hubungna isi dengan topik, (6) penguasaan cerita. Hal tersebut ialah faktor yang mempengaruhi keterampilan berbicara peserta didik. Ketiga, subjek penelitian ialah melibatkan peserta didik kelas IX SMP Negeri

1 Pariaman tahun ajaran 2018/2019. Pembatasan ini dilakukan karena disesuaikan dengan pogram pembelajaran bahasa Indonesia pada semester ketika penelitian dilakukan.

\section{METODE PENELITIAN}

Metode penelitian yang digunakan adalah metode eksperimen. Jenis penelitian ini adalah penelitian kuantitatif. Rancangan penelitian yang digunakan yaitu One Group Pretest-Posttest Design karena menggunakan satu kelompok sampel. Populasi dalam penelitian ini adalah peserta didik kelas IX SMP Negeri 1 Pariaman sedangkan sampel penelitian yang digunakan ialah teknik purposive sampling. Dalam penelitian ini terdapat dua variabel, yaitu keterampilan berbicara sebelum menerapkan teknik mind mapping dan setelah menggunakan teknik mind mapping. Instrumen penelitian yang digunakan untuk mengumpulkan data ialah tes keterampilan berbicara peserta didik. Teknik pengumpulan data yang dilakukan dalam penelitian ini adalah memberikan tes berupa pretest dan posttest kepada sampel penelitian. Setelah data terkumpul, langkah selanjutnya adalah berikut ini. Pertama, mengubah skor tes keterampilan berbicara peserta didik sebelum dan sesudah menggunakan teknik min mapping. Kedua, menentukan nilai rata-rata hitung keterampilan berbicara peserta didik. Ketiga, menafsirkan hasil belajar terampil berbiacar peserta didik berdasarkan rata-rata hitung KKM. Keempat, mengklasifikasikan nilai keterampilan berbicara peserta didik sebelum dan sesudah menggunakan teknik mind mapping. Kelima, membuat histogram hasil belajar terampil berbicara peserta didik. Keenam, melakukan uji normalitas dan homogenitas data. Ketujuh, melakukan pengujian hipotesis untuk melihat pengaruh penggunaan teknik mind mapping terhadap keterampilan berbicara peserta didik di depan kelas.

\section{HASIL DAN PEMBAHASAN}

Pada bagian ini akan dipaparkan dua hal yang berhubungan dengan hasil penelitian. Pertama, Deskripsi data, yang berarti mendeskripsikan data yang sudah terkumpul. Kedua, analisis data yang dilakukan sesuai dengan langkah-langkah penganalisisan data.Penelitian dilakukan terahadap peserta didik kelas IX SMP Negeri 1 Pariaman. Kelas yang dijadikan penelitian adalah kelas IX SMP Negeri 1 Pariaman dari hasil tes keterampilan berbicara menceritakan salah seorang tokoh pahlawan Indonesia sebelum dan sesudah menggunakan teknik mind mapping. 
Selanjutnya analisis data keterampilan berbicara peserta didik peserta didik kelas IX SMP Negeri 1 Pariaman dengan menggunakan teknik mind mapping dapat dilakukan dengan analisis per indikator. Adapun indikator yang dinilai adalah sebagai berikut. Pertama, indikator I (lafal dan intonasi). Rata-rata hitung indikator I keterampilan berbicara peserta didik kelas IX SMP Negeri 1 Pariaman dengan menggunakan teknik mind mapping adalah 76,67 dengan kualifikasi Baik (B). Kedua, indikator II (struktur bahasa). Rata-rata hitung indikator II berbicara peserta didik kelas IX SMP Negeri 1 Pariaman dengan menggunakan teknik mind mapping adalah 75,33 dengan kualifikasi Baik (B). Ketiga, indikator III (pilihan kata). Rata-rata hitung indikator III keterampilan berbicara peserta didik kelas IX SMP Negeri 1 Pariaman dengan menggunakan teknik mind mapping adalah 88,67 dengan kualifikasi Baik Sekali (BS). Keempat, indikator IV (kelancaran). Rata-rata hitung indikator IV keterampilan berbicara peserta didik kelas VII SMP Negeri 16 Padang dengan menggunakan teknik mind mapping adalah 75,33 dengan kualifikasi lebih dari cukup . Kelima, indikator $\mathrm{V}$ (hubungan isi dengan topik). Rata-rata hitung indikator V keterampilan berbicara peserta didik kelas IX SMP Negeri 1 Pariaman dengan menggunakan teknik mind mapping adalah 84,67 dengan kualifikasi Baik (B). Keenam, indikator VI (kelancaran). Rata-rata

Data keterampilan berbicara peserta didik kelas IX SMP Negeri 1 Pariaman sebelum menggunakan teknik mind mapping adalah melalui tes awal yang diberikan kepada peserta didik kelas IX A yang terdiri atas 25 orang. Tes tersebut berupa tes untuk kerja. Soal yang diberikan meliputi enam indikator, yaitu (1) lafal dan intonasi, (2) struktur bahasa, (3) pilihan kata, (4) kalancara, (5) hubungna isi dengan topik, (6) penguasaan cerita. (Tabel 1) data keterampilan berbicara peserta didik kelas IX SMP Negeri 1 Pariaman sebelum menggunakan teknik mind mapping.

Tabel 1 Keterampilan Berbicara Peserta didik Kelas IX SMP Negeri 1 Pariaman

Sebelum Menggunakan Teknik Mind Mapping

\begin{tabular}{|c|c|c|c|}
\hline NO & Skor & Frekuensi & $\begin{array}{c}\text { Persentase } \\
(\mathbf{\%})\end{array}$ \\
\hline $\mathbf{1}$ & 15,0 & 1 & 4 \\
\hline $\mathbf{2}$ & 14,5 & 1 & 4 \\
\hline $\mathbf{3}$ & 14,0 & 1 & 4 \\
\hline $\mathbf{4}$ & 13,5 & 4 & 16 \\
\hline $\mathbf{5}$ & 13,0 & 1 & 4 \\
\hline $\mathbf{6}$ & 12,5 & 3 & 12 \\
\hline $\mathbf{7}$ & 12,5 & 3 & 12 \\
\hline $\mathbf{8}$ & 11,5 & 3 & 12 \\
\hline $\mathbf{9}$ & 11,5 & 1 & 4 \\
\hline $\mathbf{1 0}$ & 10,5 & 4 & 16 \\
\hline $\mathbf{1 1}$ & 10,5 & 1 & 4 \\
\hline $\mathbf{1 2}$ & 9,5 & 2 & 8 \\
\hline & & 25 & 100 \\
\hline
\end{tabular}

Perolehan skor keterampilan berbicara peserta didik kelas IX SMP Negeri 1 Kota Pariamn sebelum menggunakan teknik mind mapping sebagai Tabel 2 berikut ini.

Tabel 2 Skor perolehan per-Indikator Keterampilan Berbicara Peserta didik Kelas IX SMP Negeri 1 Pariaman sebelum Menggunakan Tekn Mind Mapping 


\begin{tabular}{|c|c|c|c|c|}
\hline NO & Indikator & Skor & Frekuensi & $\begin{array}{c}\text { Persentase } \\
(\%)\end{array}$ \\
\hline \multirow{5}{*}{1} & \multirow{5}{*}{$\begin{array}{l}\text { Lafal } \\
\text { dan } \\
\text { Intonasi }\end{array}$} & 3,0 & 1 & 4 \\
\hline & & 2,5 & 8 & 16 \\
\hline & & 2,0 & 12 & 48 \\
\hline & & 1,5 & 6 & 24 \\
\hline & & 1,0 & 2 & 8 \\
\hline \multirow{5}{*}{2} & \multirow{5}{*}{$\begin{array}{c}\text { Struktur } \\
\text { Bahasa }\end{array}$} & 3,0 & 3 & 12 \\
\hline & & 2,5 & 8 & 32 \\
\hline & & 2,0 & 8 & 32 \\
\hline & & 1,5 & 5 & 20 \\
\hline & & 1,0 & 1 & 4 \\
\hline \multirow{4}{*}{3} & \multirow{4}{*}{$\begin{array}{c}\text { Pilihan } \\
\text { Kata }\end{array}$} & 3,0 & 1 & 4 \\
\hline & & 2,5 & 15 & 60 \\
\hline & & 2,0 & 5 & 20 \\
\hline & & 1,5 & 4 & 16 \\
\hline \multirow{4}{*}{4} & \multirow{4}{*}{$\begin{array}{l}\text { Kelanca } \\
\text { ran }\end{array}$} & 2,5 & 7 & 28 \\
\hline & & 2,0 & 8 & 32 \\
\hline & & 2,0 & 8 & 32 \\
\hline & & 1,5 & 2 & 8 \\
\hline \multirow{4}{*}{5} & \multirow{4}{*}{$\begin{array}{l}\text { Hubung } \\
\text { an Isi } \\
\text { dengan } \\
\text { Topik }\end{array}$} & 3,0 & 3 & 12 \\
\hline & & 2,5 & 11 & 44 \\
\hline & & 2,0 & 4 & 16 \\
\hline & & 1,5 & 7 & 28 \\
\hline \multirow{5}{*}{6} & \multirow{5}{*}{$\begin{array}{c}\text { Penguas } \\
\text { aan }\end{array}$} & 3,0 & 1 & 4 \\
\hline & & 2,5 & 1 & 4 \\
\hline & & 2,0 & 4 & 16 \\
\hline & & 1,5 & 15 & 60 \\
\hline & & 1,0 & 4 & 16 \\
\hline
\end{tabular}

Berdasarkan Tabel 2 keterampilan berbicara per-indikator peserta didik kelas IX SMP Negeri 1 Pariaman (Tabel 2) sebelum menggunakan teknik mind mapping. Pertama untuk indikator I (lafal dan intonasi) nilai keterampilan berbicara peserta didik sebelum menggunakan teknik mind mapping berada pada kualifikasi Cukup (C) dengan rata-rata 64,0008 Kedua, untuk indikator II (struktur bahasa) sebelum menggunakan teknik mind mapping berada pada kualifikasi lebih dari cukup dengan rata-rata 74,8532 . Ketiga, untuk indikator III (pilihan kata) berada pada kualifikasi baik (B) dengan rata-rata 75,332. Keempat, untuk indikator IV (Kelancaran) berada pada kualifikasi lebih dari cukup dengan rata-rata 63,3332. Kelima, untuk indikator V (Hubungan isi dengan Topik) berada pada kualifikasi lebih dari cukup dengan rata-rata 73,3324. Keenam, untuk indikator (Penguasaan Cerita) berada pada kualifikasi hampir cukup dengan rata-rata 53,3332 .

Data keterampilan berbicara peserta didik kelas IX SMP Negeri 1 Pariaman sesudah menggunakan teknik mind mapping adalah melalui tes akhir yang diberikan kepada peserta didik kelas IX SMP Negeri 1 Pariaman yang terdiri atas 25 peserta didik. Tes tersebut berupa tes unjuk kerja. Soal yang diujikan meliputi tiga indikator, yaitu (1) lafal dan intonasi, (2) struktur bahasa, (3) pilihan kata, (4) kelancaran, (5) hubungan isi dan topik, dan (6) penguasaan isi cerita.

Data keterampilan berbicara peserta didik sesudah menggunakan teknik mind mapping dideskripsikan sebagai berikut. Pertama, peserta didik yang memperoleh skor tertinggi (16) berjumlah 2 orang (8\%). Kedua, peserta didik yang memperoleh skor $(15,5)$ berjumlah 7 orang (28\%). Ketiga, peserta didik yang memperoleh skor (15) 4 orang (16\%). Keempat, peserta didik yang memperoleh skor $(14,5)$ berjumlah 6 orang (24\%). Kelima, 
peserta didik yang memperoleh sor (14) berjumlah 2 orang (8\%). Keenam, peserta didik yang memperoleh skor $(13,5)$ berjumlah 2 orang (8\%). Ketujuh, peserta didik yang memperoleh skor (13) berjumlah 1 orang (4\%). Kedelapan, peserta didik yang memperoleh skor $(12,5)$ berjumlah 1 orang $(4 \%)$.

Selengkapnya, perolehan skor keterampilan berbicara peserta didik kelas IX SMP Negeri 1 Pariaman sesudah menggunakan teknik mid mapping pada tabel 3 berikut ini.

Tabel 3 Skor perolehan per-Indikator Keterampilan Berbicara Peserta didik Kelas IX SMP Negeri 1 Pariaman sesudah Menggunakan Tekn Mind Mapping

\begin{tabular}{|c|c|c|c|c|}
\hline NO & Indikator & Skor & $\begin{array}{l}\text { Frekuens } \\
\mathbf{i}\end{array}$ & $\begin{array}{c}\text { Perse } \\
\text { ntase } \\
(\%)\end{array}$ \\
\hline \multirow{4}{*}{1} & \multirow{4}{*}{$\begin{array}{l}\text { Lafal } \\
\text { dan } \\
\text { Intonasi }\end{array}$} & 3,0 & 2 & 8 \\
\hline & & 2,5 & 13 & 52 \\
\hline & & 2,0 & 8 & 32 \\
\hline & & 1,0 & 2 & 8 \\
\hline \multirow{5}{*}{2} & \multirow{5}{*}{$\begin{array}{c}\text { Struktur } \\
\text { Bahasa }\end{array}$} & 3,0 & 3 & 12 \\
\hline & & 2,5 & 12 & 48 \\
\hline & & 2,0 & 6 & 24 \\
\hline & & 1,5 & 3 & 12 \\
\hline & & 1,0 & 1 & 4 \\
\hline \multirow{4}{*}{3} & \multirow{4}{*}{$\begin{array}{c}\text { Pilihan } \\
\text { Kata }\end{array}$} & 3,0 & 10 & 40 \\
\hline & & 2,5 & 13 & 52 \\
\hline & & 2,0 & 5 & 8 \\
\hline & & 1,5 & 4 & 8 \\
\hline \multirow{4}{*}{4} & \multirow{4}{*}{$\begin{array}{c}\text { Kelancar } \\
\text { an }\end{array}$} & 2,5 & 7 & 52 \\
\hline & & 2,0 & 13 & 28 \\
\hline & & 2,0 & 7 & 8 \\
\hline & & 1,5 & 2 & 4 \\
\hline 5 & Hubunga & 3,0 & 6 & 24 \\
\hline
\end{tabular}

\begin{tabular}{|c|c|c|c|c|}
\hline \multirow{4}{*}{$\begin{array}{c}\text { n Isi } \\
\text { dengan } \\
\text { Topik }\end{array}$} & 2,5 & 16 & 64 \\
\cline { 3 - 5 } & 2,0 & 2 & 8 \\
\cline { 3 - 5 } $\mathbf{6}$ & 1,5 & 1 & 4 \\
\hline \multirow{2}{*}{$\begin{array}{c}\text { Penguas } \\
\text { aan } \\
\text { Cerita }\end{array}$} & 2,5 & 12 & 48 \\
\cline { 3 - 5 } & & 2,0 & 4 & 8 \\
\cline { 3 - 5 } & 1,5 & 2 & 0 \\
\cline { 3 - 5 } & 1,0 & 1 & 0 \\
\hline
\end{tabular}

Berikut ini akan dijelaskan per-indikator keterampilan berbicara peserta didik kelas IX SMP Negeri 1 Pariaman sesudah menggunakan teknik mind mapping. Berdasarkan rata-rata hitung tersebut, disimpulkan bahwa nilai keterampilan berbicara peserta didik kelas IX SMP Negeri 1 Pariaman sesudah menggunakan teknik mind mapping yaitu berikut ini. Pertama, untuk indikator 1 (lafal dan intonasi) berada pada kualifikasi baik (B), dengan rata-rata 76,66. Kedua, untuk indikator II (struktur bahasa) berada pada kualifikasi baik (B) dengan ratarata 75,33. Ketiga, untuk indikator III (pilihan kata) berada pada kualifikasi baik sekali, dengan rata-rata 88,66. Keempat, untuk indikator IV (kelancaran) berada pada kualifikasi lebih dari cukup dengan rata-rata 73,99. Keempat, untuk indikator V (hubungan isi dengan topik) berada pada kualifikasi baik (B) dengan rata-rata 84,66. Kelima, untuk indikator VI (penguasaan kosakata) berada kualifikasi baik (B) dengan rata-rata 84,66.

Analisis data diuraikan berdasarkan langkah-langah berikut ini. Pertama, menganalisis keterampilan berbicara peserta didik tanpa menggunakan teknik mind mapping. Kedua, menganalisis keterampilan 
berbicara peserta didik dengan menggunakan teknik mind mapping. Ketiga, membandingkan hasil tek keterampilan berbicara peserta didik sebelum menggunakan teknik mind mappingpeserta didik kelas IX SMP Negeri 1 Pariaman.

Keterampilan berbicara peserta didik kelas IX SMP Negeri 1 Pariaman sebelum menggunakan teknik mind mapping. Proses penganalisisan data sebelum menggunakan teknik mind mapping per indikator selengkapnya dapat dilihat pada uraian berikut. Pertama, peserta didik memperoleh nilai 77,78 (Baik). Kedua, peserta didik memperoleh nilai 69,64 (Lebih dari Cukup). Ketiga, peserta didik memperoleh nilai 61,1 (Cukup). Keempat, peserta didik memperoleh nilai 52,72 (Hampir Cukup). Keterampilan berbicara peserta didik kelas IX SMP Negeri 1 Pariaman sesudah menggunakan teknik mind mapping. Proses penganalisisan data sesudah menggunakan teknik mind mapping per indikator selengkapnya dapat dilihat pada uraian berikut. Pertama, peserta didik memperoleh nilai 86,11 (Baik Sekali). Kedua, peserta didik memperoleh nilai 80,56 (Baik Sekali). Ketiga, peserta didik memperoleh nilai 69,44 (Lebih dari Cukup). Keempat, peserta didik memperoleh nilai 65, 66 (Lebih dari Cukup).

Selanjutnya pengaruh nilai keterampilan berbicara sebelum dan sesudah menggunakan teknik mind mapping peserta didik kelas IX SMP Negeri 1 Pariaman. Untuk menjawab hipotesis penelitian yang menyatakan bahwa ada atau tidaknya pengaruh teknik mind mapping dalam pembelajaran keterampilan berbicara peserta didik kelas IX SMP Negeri 1

Pariaman diketahui dengan cara membandingkan keterampilan berbicara peserta didik kelas IX SMP Negeri 1 Pariaman sebelum dan sesudah menggunakan teknik mind mapping (Tabel 4)

Tabel 4 Perbadingan Keterampilan Berbicara Peserta didik Kelas IX SMP Negeri 1 Pariaman sebelum dan sesudah Menggunakan Teknik Mind Mapping

\begin{tabular}{|c|c|c|c|c|c|}
\hline NO & Kelompok & $\mathbf{N}$ & $\sum \mathbf{X}$ & $\sum \mathbf{X}^{\mathbf{2}}$ & $\begin{array}{c}\text { Rata- } \\
\text { rata }\end{array}$ \\
\hline 1. & Pretest & 25 & 1669,44 & 113247,82 & 66,777 \\
\hline 2. & Posttest & 25 & 2044,45 & 167809,52 & 81,778 \\
\hline
\end{tabular}

Berdasarkan tabel 4 tersebut, dapat dilakukan uji-t untuk mengetahui pengaruh keterampilan berbicara sebelum dan sesudah menggunakan teknik mind mapping peserta didik kelas IX SMP Negeri 1 Pariaman. Sebelum dilakukan uji-t, terlebih dahulu dilakukan uji persyaratan analisis untuk menentukan data dan uji-t homogenitas data. Disimpulkan bahwa hipotesis alternatif (H1) diterima pada taraf signifikan $95 \%$ dan $\mathrm{dk}=\mathrm{n}-1$ karena thitung $>$ ttabel $(7,23>1,21)$. Dengan kata lain, penggunaan teknik mind mappping berpengaruh secara signifikan terhadap keterampilan berbicara peserta didik kelas IX SMP Negeri 1 Pariaman. Hal ini juga terlihat dari rata-rata berbicara peserta didik sesudah menggunakan teknik mind mapping lebih tinggi dibandingkan sebelum menggunakan teknik mind mapping.

Berdasarkan analisis data, diperoleh rata-rata hitung keterampilan berbicara peserta didik kelas IX SMP Negeri 1 Pariaman 
sebelum dan sesudah menggunakan teknik mind mapping. Rata-rata hitung tersebut dapat disimpulkan bahwa keterampilan berbicara peserta didik kelas IX SMP Negeri 1 Pariaman sebelum menggunakan teknik mind mapping sebesar 66,78 tergolong lebih dari cukup. Ratarata hitung tersebut dapat disimpulkan bahwa keterampilan berbicara peserta didik kelas IX SMP Negeri 1 Pariaman sebelum menggunakan teknik mind mapping sebesar 81,78 tergolong Baik (B).

Arief.dkk (2003) berpendapat bahwa hal yang perlu diperhatikan dalam berbicara diantaranya ketepatan ucapa, penempatam tekanan, nada, dan durasi. Hal ini disebabkan karena sebelum menceritaka tokoh idola peserta didik diberikan materi tentang keterampilan berbicara dengan menggunakan tenik mind mapping oleh guru. Selnjutnya guru juga memberikan contoh cara menceritakan tokoh idola berdasarka mind mapping keada peserta didik di dalam kelas. Sebagimana meenurut Immaduddin, dkk (2012) mind mapping lebih cepat dan efisien.

Teknik mind mapping sangat cocok diterapkan dalam pembelajaran keterampilan berbicara. Dengan teknik yang digunakan tersebut peserta didik terampil dalam berbicara khususnya menceritakan tokoh idola. Pembelajaran keterampilan berbicara saat menggunakan teknik mind mapping sangat menarik bagi peserta didik. Peserta didik terlihat antusias saat guru menggunakan teknik tersebut dan pada saat mereka menggunakannya juga. Hal ini sejalan dengan pendapat Menurut Suhendar dan Supiah (2012) yang menyatakan bahwa ada empat manfaat mind map, yaitu (1) mampu meningkatkan kapasitas pemahaman, (2) meningkatkan kemampuan seseorang dalam berimajinasi, mengingat, berkonsentrasi, membuat catatan, meningkatkan minat sekaligus mampu menyelesaikan persoalan, (3) merangsang sisi kreatif seseorang lewat penggunaan baris lengkung, warna dan gambar, dan (4) membantu seseorang membuat catatan yang menarik dalam waktu singkat.

Pembelajaran menggunakan teknik mind mapping sangat membantu guru dalam membimbing peserta didik. Peserta didik terlihat serius mengikuti pembelajaran saat menggunakan teknik mind mapping. Peserta didik juga tampak antusias saat peneliti mencontohkan menceritakan tokoh idola dengan menggunakan mind mapping.

Lembar hasil pengamatan peserta didik dilakukan selama proses pembelajaran keterampilan berbicara dengan menggunakan teknik mind mapping. Hasil pengamatan sangat menarik bagi peserta didik. Berdasarkan hasil pengamatan guru dari aktivitas positif peserta didik dalam mengikuti pembelajaran keterampilan berbicara pada peserta didik kelas IX SMP Negeri 1 Pariaman setelah menggunakan teknik mind mapping tergolong baik.

Ditinjau dari hasil tes keterampilan berbicara peserta didik kelas IX SMP Negeri 1 Pariaman setelah menggunakan teknik mind mapping lebih tinggi dibandingkan dengan sebelum menggunakan teknik mind mapping. Hal ini berarti teknik mind mapping berpengaruh terhadap keterampilan berbicara peserta didik kelas IX SMP Negeri 1 Pariaman. 
Teknik mind mapping sangat cocok diterapkan dalam pembelajaran keterampilan berbicara. Dengan teknik yang digunakan tersebut peserta didik keterampilan berbicara khususnya menceritakan tokoh pahlawan Indonesia dan yang lainnya. Pembelajaran keterampilan berbicara saat menggunakan teknik mind mapping sangat menarik peserta didik. Peserta didik terlihat antusias saat guru menggunakan teknik tersebut peserta didik terampil dalam berbicara. Hal ini sejalan dengan pendapat Tarigan, Henry Guntur (2008) yang meyatakan bahwa ada empat manfaat mind mapping, yaitu (1) mampu meningkatkan kapasitas pemahaman, (2) meningkatkan kemampuan seseorang dalam berimajinasi, mengingat, berkonsentrasi, membuat catatan, meningkatkan minat sekaligus mampu menyelesaikan persoalan, (3) merangsang sisi kreatif seseorang lewat penggunaan baris lengkung, warna, dan gambar, dan (4) membantu seseorang membuat catatan yang menarik dalam waktu singkat.

Pembelajaran menggunakan teknik mind mapping sangat membantu guru dalam membimbing peserta didik. Peserta didik sungguh-sungguh dan seksama dalam mengikuti pembelajaran di kelas saat menggunakan teknik mind mapping. Peserta didik terlihat mengikuti pembelajaran saat menggunakan teknik mind mapping. Peserta didik merasa tertarik karena merasa menemukan hal yang baru pada saat pembelajaran menggunakan teknik mind mapping.

\section{SIMPULAN DAN SARAN \\ SIMPULAN}

Pengaruh penggunaan teknik mind mapping terhadap keterampilan berbicara peserta didik kelas IX SMP Negeri 1 Pariaman karena thitung $>$ ttabel yaitu $(7,23>1,71)$. Dengan demikian H1diterima dan H0 ditolak karena hasil pengujian membuktikan bahwa thitung $>$ ttabel. Jadi, disimpulkan berbicara peserta didik kelas IX SMP Negeri 1 Pariaman.

\section{SARAN}

Tehnik mind mapping dapat digunakan untuk meningkatkan keterampilan berbicara.

\section{DAFTAR PUSTAKA}

Aini,Annisa, Andayani dan Atikah Anindyarini. 2012.”Metode Mind Mapping untuk Meningkatkan Keterampilan Berbicara Peserta didik Sekolah Dasar". Jurnal penelitian bahasa, sastra, dan Indonesia dan Pengajarannya, Vol,1,No 1, Desember 2012. Universitas Surakarta: Universitas ebelas Maret.

Arief, Ermawati dan Yarni Munaf. 2003. "Pengajaran Keterampilan Berbicara (Buku Ajar). Padang: Jurusan bahasa dan Sastra Indonesia FBSS UNP.

Immaduddin, Muhammad Chomsi dan Unggul Haryanto N.U. (2012). "Efektifitas Metode Mind Mapping untuk Meningkatkan Prestasi Belajar Fisika pada Peserta didik Kelas VIII". Jurnal ilmiah Fakultas Psikologi Universitas Ahmad Bahlan Yogyakarta, Vol IX, No. 1, Januari 2015. Yogyakarta. Universitas Ahmad Bahlan. 
Suhendar dan Supinah. 2012. Bahasa Indonesia. Pengajaran dan Ujian Keterampilan Menemukan. Bandung: Pioneer Jaya.

Tarigan, Henry Guntur. 2008. Berbicara sebagai Suatu Keterampilan

Berbahasa. Bandung:Angkasa. 